\title{
Quantifying and characterizing hourly human exposure to malaria vectors bites to address residual malaria transmission during dry and rainy seasons in rural Southwest Burkina Faso
}

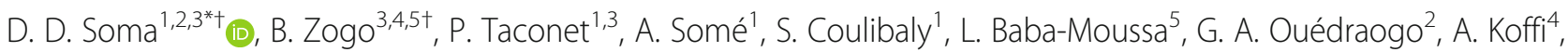 \\ C. Pennetier ${ }^{3,4}$, K. R. Dabiré ${ }^{\text {and N. Moiroux }}{ }^{1,3}$
}

\begin{abstract}
Background: To sustain the efficacy of malaria vector control, the World Health Organization (WHO) recommends the combination of effective tools. Before designing and implementing additional strategies in any setting, it is critical to monitor or predict when and where transmission occurs. However, to date, very few studies have quantified the behavioural interactions between humans and Anopheles vectors in Africa. Here, we characterized residual transmission in a rural area of Burkina Faso where long lasting insecticidal nets (LLIN) are widely used.

Methods: We analysed data on both human and malaria vectors behaviours from 27 villages to measure hourly human exposure to vector bites in dry and rainy seasons using a mathematical model. We estimated the protective efficacy of LLINs and characterised where (indoors vs. outdoors) and when both LLIN users and non-users were exposed to vector bites.

Results: The percentage of the population who declared sleeping under a LLIN the previous night was very high regardless of the season, with an average LLIN use ranging from 92.43 to $99.89 \%$. The use of LLIN provided $>80 \%$ protection against exposure to vector bites. The proportion of exposure for LLIN users was 29-57\% after 05:00 and $0.05-12 \%$ before $20: 00$. More than $80 \%$ of exposure occurred indoors for LLIN users and the estimate reached $90 \%$ for children under 5 years old in the dry cold season.
\end{abstract}

Conclusions: LLINs are predicted to provide considerable protection against exposure to malaria vector bites in the rural area of Diébougou. Nevertheless, LLIN users are still exposed to vector bites which occurred mostly indoors in late morning. Therefore, complementary strategies targeting indoor biting vectors in combination with LLIN are expected to be the most efficient to control residual malaria transmission in this area.

Keywords: Diébougou, LLIN, Anopheles, Humans, Behaviours, Residual transmission

\footnotetext{
* Correspondence: dieusoma@yahoo.fr

${ }^{\dagger}$ D. D. Soma and B. Zogo contributed equally to this work.

'Institut de Recherche en Sciences de la Santé (IRSS), Bobo-Dioulasso,

Burkina Faso

Université Nazi Boni (UNB), Bobo-Dioulasso, Burkina Faso

Full list of author information is available at the end of the article
}

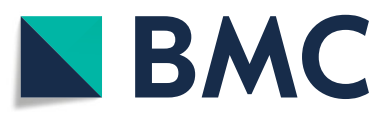

(๑) The Author(s). 2021 Open Access This article is licensed under a Creative Commons Attribution 4.0 International License, which permits use, sharing, adaptation, distribution and reproduction in any medium or format, as long as you give appropriate credit to the original author(s) and the source, provide a link to the Creative Commons licence, and indicate if changes were made. The images or other third party material in this article are included in the article's Creative Commons licence, unless indicated otherwise in a credit line to the material. If material is not included in the article's Creative Commons licence and your intended use is not permitted by statutory regulation or exceeds the permitted use, you will need to obtain permission directly from the copyright holder. To view a copy of this licence, visit http://creativecommons.org/licenses/by/4.0/ The Creative Commons Public Domain Dedication waiver (http://creativecommons.org/publicdomain/zero/1.0/) applies to the data made available in this article, unless otherwise stated in a credit line to the data. 


\section{Background}

Massive distribution of long-lasting insecticidal nets (LLINs) is a core intervention for malaria control in Burkina Faso. Scaling-up of coverage with LLIN in subSaharan Africa has been very successful between 2000 and 2015 during which malaria morbidity and mortality have dropped considerably [1]. Unfortunately, this significant progress is stalling or even reversing in some countries. Burkina Faso is indeed one of the sixteen (16) in the world that documented an increase in malaria burden from 2016 to 2017 [2]. This trend might be attributed to the recent increases in prevalence and strength of pyrethroid resistance in malaria vectors [35]. Another possible cause is the development of behavioural resistance in vector populations [6-8]. In subSaharan Africa, there have been many reports of changes in vector species and/or vector biting behaviours to avoid contact with LLIN [6-8]. Such changes in vector populations are considered by many specialists as an important threat for indoor control strategies such as LLIN $[9,10]$.

To sustain the efficacy of vector control, the WHO recommends the combination of effective tools [11]. At present, there are a number of recommended tools available and many others under development that can potentially be combined with LLIN [12, 13]. However, national malaria control programs (NMCPs) are now facing challenges to design effective control strategies due to high variations in malaria epidemiology between and even within countries [14]. To do so, NMCP must be able to monitor or predict when and where transmission occurs and to characterize residual transmission (i.e. the transmission that escapes vector control by LLINs).

In order to compare the impact of LLINs on human exposure to malaria vectors bite among sites, Killeen et al. [15] developed an approach that quantify behavioural interactions between mosquitoes and humans. The approach use measures of indoor and outdoor vector biting as well as the distribution of people outdoors, indoors and under LLINs for each hour of the night. It produces average hourly and nightly weighted estimates of exposure occurring indoors and outdoors as well as estimates of prevented exposure. The analytical model developed by Killeen et al. and extended by Geissbühler et al., [16] is therefore a useful tool to estimate protective efficacy of LLINs and to characterize residual transmission. Indeed, it allows to identify where (indoors vs. outdoors) and during which hours LLIN users are exposed to anopheles bite, i.e. where and when residual transmission is expected to occur. $\mathrm{Nu}$ merous studies have used this model in Africa [1530]. However until now, only one of these studies has reported exposure estimates for sites located in Burkina Faso [18].
The present study aims to provide and discuss up-todate estimates of human exposure to Anopheles bite and to characterise residual malaria transmission in an area of Burkina Faso where malaria vectors shows high levels of pyrethroid resistance [31]. Results of entomological surveys previously reported [31] were used in combination with human behavioural data to quantify, through the Killeen's model, the behavioural interactions between humans and Anopheles mosquitoes during both dry and rainy seasons in the Diébougou area, southwest Burkina Faso. Data were collected during the pre-intervention stage of a large randomized control trial designed to investigate whether the combination of LLINs with other vector control tools can provide additional protection over malaria cases and transmission.

\section{Methods}

This study was conducted in 27 villages located in the Diébougou health district, southwest Burkina Faso (Fig. 1). These villages were selected based on geographical (distance between two villages higher than $2 \mathrm{~km}$ and accessibility during the rainy season) and demographic (a population size ranging from 200 to 500 inhabitants) criteria [31] to participate in a randomized controlled trial. The climate in the study area is tropical with one dry season from October to April (including a cold period from December to February and a hot period from March to April) and one rainy season from May to September. Average daily temperature amplitudes are $18-36^{\circ} \mathrm{C}, 25-39^{\circ} \mathrm{C}$ and $23-33^{\circ} \mathrm{C}$ in dry cold, dry hot and rainy season, respectively. The mean annual rainfall is $1200 \mathrm{~mm}$. The natural vegetation is dominated by wooded savannah dotted with clear forest gallery. The main economic activity is agriculture (cotton growing and cereals) followed by artisanal gold mining and production of coal and wood [32,33]. In the study area as in the whole country, a mass distribution of LLINs (PermaNet 2.0) was carried out by the NMCP in July 2016. No LLINs were distributed by our teams.

The study involved the conduct of three entomological surveys and two human behavioural surveys. Figure 2 shows the timeline of the study. We conducted three entomological surveys in the dry cold (January 2017), dry hot (March 2017) and rainy seasons (June 2017). During each survey, we collected mosquitoes using the standard method of human landing catch (HLC). Mosquitoes were sampled both indoors and outdoors from 17:00 $\mathrm{h}$ to $09: 00 \mathrm{~h}$ in 4 houses per villages during one night [31]. In each study village, two teams of eight collectors were deployed, with the first team collecting from 17:00 $\mathrm{h}$ to 01:00 $\mathrm{h}$ and the second from 01:00 $\mathrm{h}$ to 09:00 $\mathrm{h}$. All the collected mosquitoes were morphologically identified [34, 35] and Anopheles spp. mosquitoes were subsequently identified to the species level by polymerase 


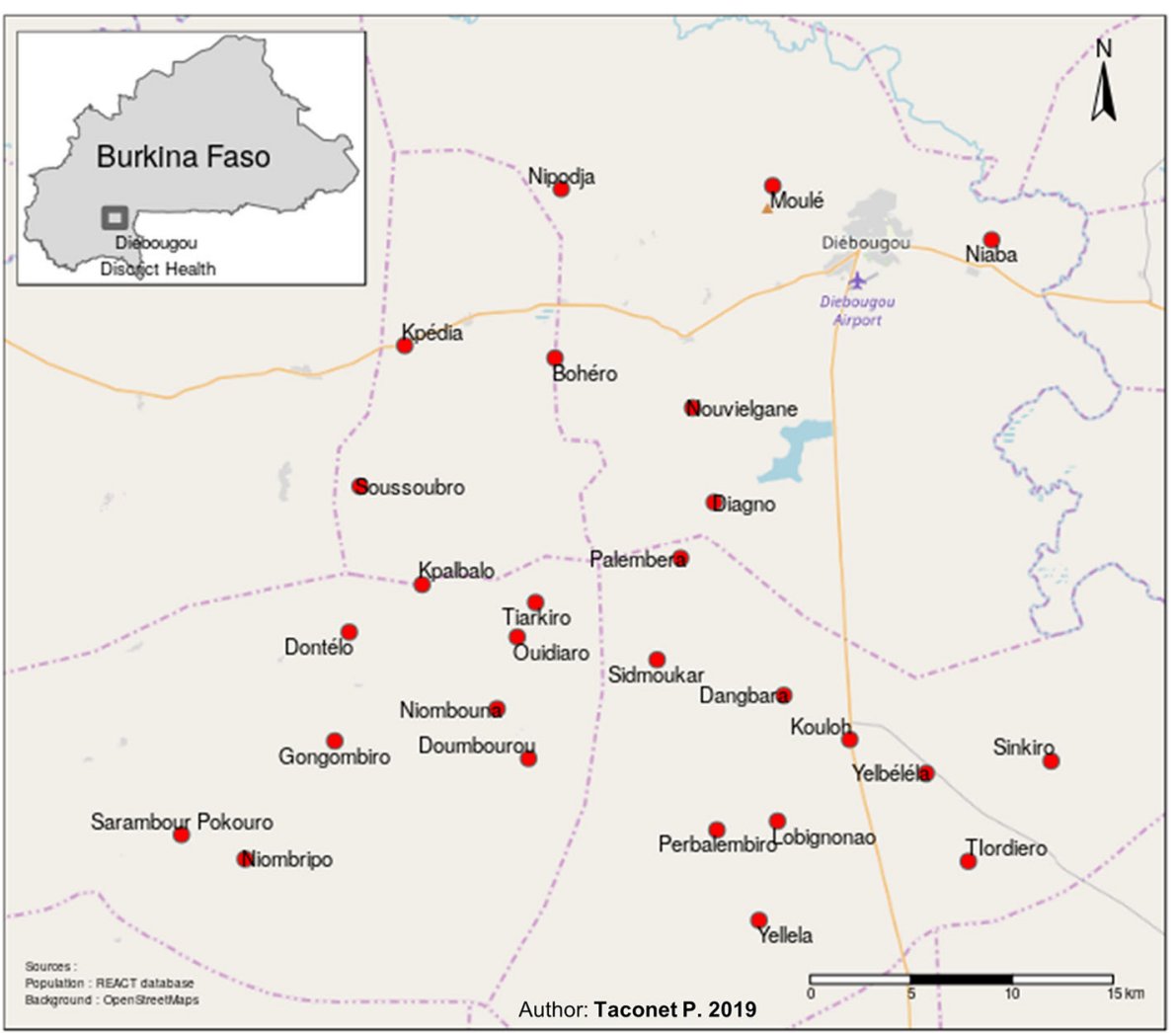

Fig. 1 Map of the study area and villages surveyed. Background of the map was produced with open data (under ODbL Licence) from openstreetmap.org. Data of village locations are own and obtained through the REACT project

chain reaction [36-38]. Detailed descriptions of the methods used are provided in our previous publication [31]. In the current work, we aggregate data for all species belonging to the Anopheles genus (Anopheles spp) in order to have appropriate data regarding malaria vectors behaviour. Overall, Anopheles funestus s.s was the main malaria vector in the study area during the dry cold season [31]. During the dry hot and rainy seasons,
Anopheles coluzzii and Anopheles gambiae s.s were the dominant species. The mean endophagy rate (ER) of malaria vectors was $63.23,50.18$ and $57.18 \%$ during the dry cold, dry hot and rainy seasons, respectively [31].

In order to obtain appropriate data regarding relevant human behaviours, we surveyed 401 and 339 randomly selected households in dry (end of February to April 2017) and rainy (September 2017) seasons, respectively

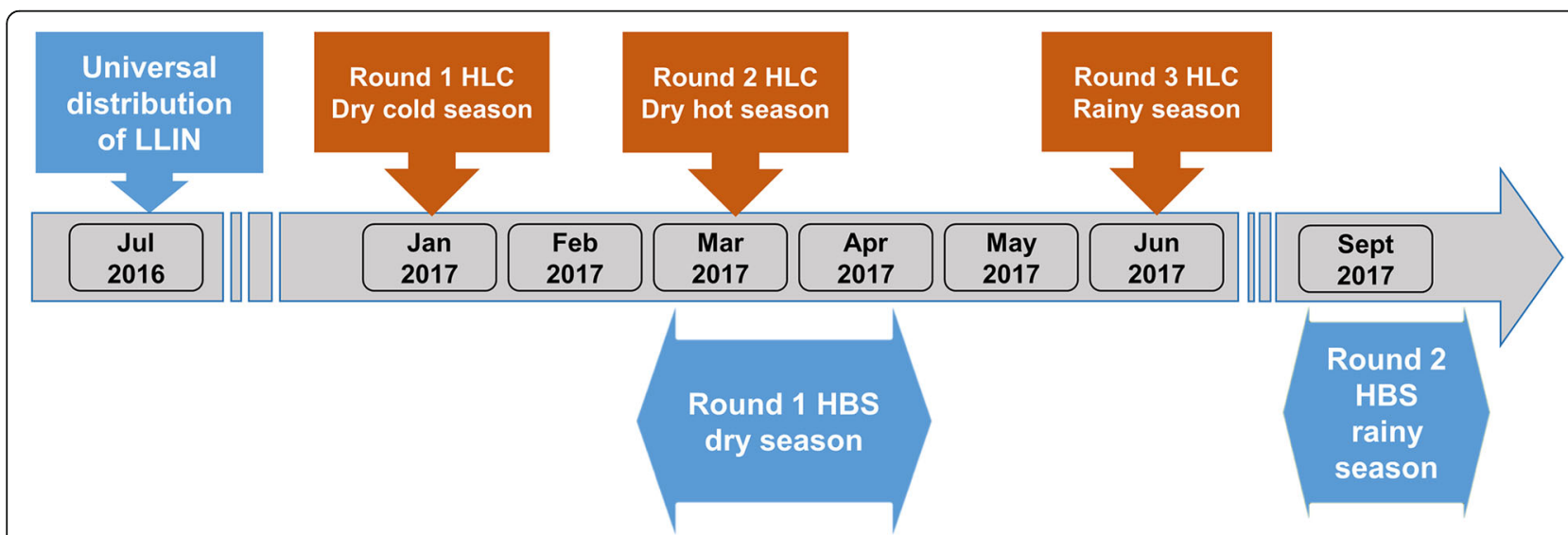

Fig. 2 Timeline of long-lasting insecticidal impregnated net (LLIN) distribution campaigns, human behaviours surveys (HBS), and entomological surveys. HLC: Human Landing Collection 
(corresponding to an average of 15 and 13 households per village). Among people usually leaving in each selected household, we randomly selected 3 persons (maximum) belonging to each of the 3 following age groups: $0-5$ years old, $6-17$ years old and $\geq 18$ years old. We asked the head of the household the time at which each selected person (1) entered and exited his own house the night preceding the survey and (2) the time each LLIN user entered and exited his sleeping space the night preceding the survey (the questionnaire was previously published in supplementary Text S1 of [20]). In order to know the relative weight of each age group in the population, we recorded the number of individuals belonging to these groups in each household. A total of 3045 and 2880 individuals were surveyed in dry and rainy seasons, respectively, representing 35.08 and $33.17 \%$ of the 27 villages' population according to a census carried out by our team in 2016 [31]. The human behavioural surveys were carried out in the same villages where mosquitoes were collected. The selections of households for human behavioural surveys and of houses for entomological survey were independent. Data were recorded using tablets running Open Data Kit (ODK) forms.

From data of each entomological survey, we calculated indoor and outdoor hourly biting rates (i.e. the number of Anopheles mosquitoes collected per human per hour) at the village level and for the whole study area. At the same scales, we calculated from data of each human behavioural survey the hourly proportions of people being indoors or under an LLIN. Hourly biting rates and hourly distribution of people were combined to calculate estimates of human exposure to Anopheles spp. bites in the dry season (both cold and hot) and the rainy season using an extension of the Killeen's model [15] as previously described in Geissbühler et al. [16] and Moiroux et al. [20] and detailed in Additional file 1.

Since only one survey of human behaviour was carried out in dry season, we used the same human behaviour data to model human exposure to Anopheles bite during both dry cold and dry hot seasons.

We estimated the average true personal protection $\left(P^{*}\right)$ of using an LLIN (i.e. the proportion of exposure to all bites occurring both indoors and outdoors that is prevented by using an LLIN) as well as the proportion of exposure which occurred indoors for LLIN users either accounting for the personal protection provided by net use $\left(\pi_{i, n}\right)$ or ignoring it to compare with available estimates for unprotected people $\left(\pi_{i}\right)$ [16] (Additional File 1). Exposure when sleeping under an LLIN was assumed to be reduced by $92 \%$ [20]. Moreover, to characterize residual transmission, we calculated the proportion of exposure occurring before 20:00 $\left(\pi_{e, n}\right)$ and after 5:00 $\left(\pi_{m, n}\right)$ that are the times respectively preceding and following the period when most $(>50 \%)$ of LLIN users are protected (Additional File 1).
All the exposure estimates (i.e. $P^{*}, \pi_{i, n}, \pi_{i}, \pi_{e, n}, \pi_{m, n}$ ) were calculated at the village and study area levels, for each age group as well as for the whole population. The relative weight of each age classes in the population was taken into account when calculating exposure values at the population level (see Additional File 1). For these calculation and to produce figures, we developed an $\mathrm{R}$ [39] package named "biteExp" (https://github.com/ Nmoiroux/biteExp).

\section{Results}

The average declared LLIN use rate was very high in the study population ranging from $95.49 \%$ in the dry season to $99.67 \%$ in the rainy season (Table 1). The declared LLIN use rate was higher in the $0-5$ years old age group ( $97.87 \%$ in the dry season to $100 \%$ in the rainy season) compared to children aged 6-17 years old $(95.36 \%$ in the dry season to $99.79 \%$ in the rainy season) and adults ( $92.45 \%$ in the dry season to $99.19 \%$ in the rainy season) (Table 1). However, we found that the LLIN use rate varied among villages (see Additional file 2) with the lowest rates observed in Kpédia (68.42\%), Palembera (71.73\%) and Diagnon (78.78\%) in the adults group during the dry season. In the other villages LLIN use rates ranged from 80 to $100 \%$ whatever the season (see Additional file 2). Figure 3 shows humans and Anopheles behaviour profiles as well as average hourly exposure and prevented exposure to bites for LLIN users in our study area.

The majority of the population was indoors from 20: 00 in both dry and rainy seasons (Fig. 3a, b and c). These populations woke up around 05:00 in the early morning in all seasons (Fig. 3a, b and c). Most of the total exposure to Anopheles bites occurred indoors (> 94\% for nonusers, Table 1) but was largely preventable by using of LLIN (Fig. 3d, e and f). Indeed, LLIN were estimated to provide average 'true' personal protection against 84.93, 80.89 and $82.82 \%$ of exposure in dry cold season, dry hot season and rainy season, respectively (Table 1, Additional file 3). The peak of exposure for users occurred indoors between 05:00 and 06:00 just before sunrise whatever the season (Fig. 3d, e and f). On average, between 33 and $57 \%$ of residual exposure of LLIN users occurred after wake up (after 5:00) depending on age groups. Early bites (before 20:00) represented less than $12 \%$ of the residual exposure of LLIN users (Table 1).

\section{Discussion}

The average declared LLIN use rate was very high (> $95 \%)$ in all age groups of our study population. The LLIN use rate was slightly higher in children under five years of age than the rest of the population. This finding is consistent with results from a multi-country analysis that revealed that the most vulnerable groups are 
Table 1 Average LLIN use rates, true average protection efficacy of LLINs against exposure to vector bites and proportions of indoors, "before bed" and "after bed" exposure to Anopheles bites for both LLIN users and non-users in 27 villages of the Diébougou area, Burkina Faso

\begin{tabular}{|c|c|c|c|c|c|c|c|c|c|}
\hline \multirow[t]{2}{*}{ Season } & \multirow[t]{2}{*}{$\begin{array}{l}\text { Age } \\
\text { (years) }\end{array}$} & \multirow{2}{*}{$\begin{array}{l}\text { LLIN use } \\
\text { rate }(\%[\mathrm{~min}- \\
\text { max]) }\end{array}$} & \multirow{2}{*}{$\begin{array}{l}{ }^{\mathrm{a}} \text { True } \\
\text { average } \\
\text { LLIN } \\
\text { personal } \\
\text { protection } \\
\text { efficacy (\% } \\
\text { [min-max]) }\end{array}$} & \multicolumn{2}{|c|}{$\begin{array}{l}\text { Exposure indoors (\%[min- } \\
\text { max]) }\end{array}$} & \multicolumn{2}{|c|}{$\begin{array}{l}\text { Exposure before } 20: 00 \\
\mathrm{~h}(\%[\min -\max ])\end{array}$} & \multicolumn{2}{|c|}{$\begin{array}{l}\text { Exposure after } 05: 00 \mathrm{~h} \\
(\%[\text { min-max] })\end{array}$} \\
\hline & & & & LLIN users & Non-users & LLIN users & Non-users & LLIN users & Non-users \\
\hline \multirow[t]{4}{*}{$\begin{array}{l}\text { Dry cold } \\
\text { season }\end{array}$} & $18+$ & $\begin{array}{l}92.45[68- \\
100]\end{array}$ & 83.44 [0-92] & 79.92 [0-100] & $96.67[0-100]$ & $\begin{array}{l}0.07[0- \\
0.13]\end{array}$ & $\begin{array}{l}0.04[0- \\
0.34]\end{array}$ & $\begin{array}{l}\text { 44.99 [0- } \\
100]\end{array}$ & 8.16 [0-100] \\
\hline & 6 to 17 & $\begin{array}{l}95.36[71- \\
100]\end{array}$ & 83.79 [0-92] & $85.44[0-100]$ & 97.64 [0-100] & $0.58[0-1]$ & $\begin{array}{l}0.12[0- \\
0.73]\end{array}$ & $\begin{array}{l}48.93[0- \\
100]\end{array}$ & 9.01 [0-100] \\
\hline & 0 to 5 & $\begin{array}{l}97.87[81- \\
100]\end{array}$ & 86.73 [0-92] & 90.52 [0-100] & 98.74 [0-100] & 3.93 [0-100] & 0.62 [0-100] & $\begin{array}{l}40.23[0- \\
100]\end{array}$ & $\begin{array}{l}12.20[0- \\
100]\end{array}$ \\
\hline & population & $\begin{array}{l}95.49[77- \\
100]\end{array}$ & 84.93 [0-92] & 85.62 [0-100] & 97.83 [0-100] & $1.66[0-100]$ & 0.31 [0-100] & $\begin{array}{l}44.50[0- \\
100]\end{array}$ & $\begin{array}{l}10.11[0- \\
100]\end{array}$ \\
\hline \multirow[t]{4}{*}{ Dry hot season } & $18+$ & $\begin{array}{l}92.45[68- \\
100]\end{array}$ & 78.00 [0-92] & $\begin{array}{l}69.57[19- \\
100]\end{array}$ & $\begin{array}{l}93.31[75- \\
100]\end{array}$ & 3.38 [0-26] & $0.82[0-1]$ & $\begin{array}{l}57.20[0- \\
100]\end{array}$ & $\begin{array}{l}13.19[0- \\
100]\end{array}$ \\
\hline & 6 to 17 & $\begin{array}{l}95.36[71- \\
100]\end{array}$ & 79.88 [2-92] & $\begin{array}{l}82.70[21- \\
100]\end{array}$ & $\begin{array}{l}96.52[72- \\
100]\end{array}$ & $4.57[0-5]$ & $0.99[0-2]$ & $\begin{array}{l}56.20[0- \\
100]\end{array}$ & $\begin{array}{l}12.27[0- \\
100]\end{array}$ \\
\hline & 0 to 5 & $\begin{array}{l}97.87[81- \\
100]\end{array}$ & $\begin{array}{l}83.63[13- \\
92]\end{array}$ & $\begin{array}{l}88.73[29- \\
100]\end{array}$ & $\begin{array}{l}98.15[82- \\
100]\end{array}$ & 11.30 [0-20] & $2.13[0-3]$ & $\begin{array}{l}43.95[0- \\
100]\end{array}$ & $\begin{array}{l}12.32[0- \\
100]\end{array}$ \\
\hline & population & $\begin{array}{l}95.49[77- \\
100]\end{array}$ & 80.89 [5-92] & $\begin{array}{l}80.54[24- \\
100]\end{array}$ & $\begin{array}{l}96.28[78- \\
100]\end{array}$ & $6.56[0-30]$ & $1.41[0-2]$ & $\begin{array}{l}52.19[0- \\
100]\end{array}$ & $\begin{array}{l}12.55[0- \\
100]\end{array}$ \\
\hline \multirow[t]{4}{*}{$\begin{array}{l}\text { Rainy } \\
\text { season }\end{array}$} & $18+$ & $\begin{array}{l}99.19[92- \\
100]\end{array}$ & $\begin{array}{l}79.13[53- \\
92]\end{array}$ & $\begin{array}{l}75.61[11- \\
100]\end{array}$ & $\begin{array}{l}94.91[62- \\
100]\end{array}$ & 10.08 [0-23] & $2.17[0-5]$ & 42.90 [0-90] & $9.81[0-44]$ \\
\hline & 6 to 17 & $\begin{array}{l}99.79[94- \\
100]\end{array}$ & $\begin{array}{l}81.83[51- \\
92]\end{array}$ & $\begin{array}{l}83.28[45- \\
100]\end{array}$ & $\begin{array}{l}96.96[91- \\
100]\end{array}$ & $10.24[0-25]$ & $2.22[0-8]$ & 48.59 [0-91] & $10.42[0-50]$ \\
\hline & 0 to 5 & 100.00 & $\begin{array}{l}87.00[72- \\
92]\end{array}$ & $\begin{array}{l}89.21[69- \\
100]\end{array}$ & $\begin{array}{l}98.60[96- \\
100]\end{array}$ & 11.33 [0-19] & $2.31[0-11]$ & 33.88 [0-85] & $10.55[0-50]$ \\
\hline & population & $\begin{array}{l}99.67 \text { [97- } \\
100]\end{array}$ & $\begin{array}{l}82.82[58- \\
92]\end{array}$ & $\begin{array}{l}81.93 \text { [27- } \\
100]\end{array}$ & $\begin{array}{l}96.90[82- \\
100]\end{array}$ & 10.47 [0-23] & 2.23 [0-9] & 42.40 [0-89] & $10.27[0-48]$ \\
\hline
\end{tabular}

Min and max reported in brackets give the value recorded in the village with the lower and the higher average value, respectively

${ }^{a}$ True average LLIN personal protection efficacy: estimated proportion of Anopheles bites prevented by the use of a LLIN

preferentially protected by LLIN in sub-Saharan Africa [40]. At the village level, the use rate rarely fall under $80 \%$, being consistently higher than the nationwide LLIN use value of $67 \%$ published by WHO in 2017 [41]. This may be explained by the fact that the study was conducted approximately 6 months after a wide LLIN distribution. However, our reported LLIN use may be overestimated because it was based on self-reported survey questions, the most commonly used method to assess bednet use [42]. To more accurately estimate LLIN use, future studies quantifying human exposure to mosquito bites should consider using other measurement methods such as electronic monitoring devices [43, 44].

This study shows that the overall protective efficacy of LLINs against vector bites in the rural area of Diébougou was high $(80-85 \%)$ during the three seasons. Our estimates for LLIN personal efficacy were comparable with those found in Benin (80 and 87\%) [20] but were higher than those reported elsewhere such as in Kenya (51\%) [21] and Tanzania (70, 59 and 38\%) $[15,16]$. Our results support strongly the use of LLIN as a primary malaria vector control tool in the area. Nevertheless, such a protection level ( $85 \%$ in average) has to be put into perspective with the high malaria transmission and endemicity [31] in order to measure/realize the importance of malaria residual transmission in the area.

We estimated that $33-57 \%$ of residual exposure to Anopheles bites of LLIN users occurred after 5:00 and 0.07-12\% occurred before 20:00 when most of users are awake. The proportion of exposure for LLIN users has been higher in the late part of the morning than in the early part of the evening in some settings while the opposite trend has been observed in other settings $[15,20$, $23,45]$. In our study area, over $80 \%$ of human exposure to vector bites occurred indoors for LLIN users. For children under 5 years who use LLINs, the exposure rate occurring indoors reached $90 \%$. Therefore, these results suggest that adding other indoor intervention such as indoor residual spraying (IRS) to LLINs would be relevant to reduce malaria transmission in the rural area of 

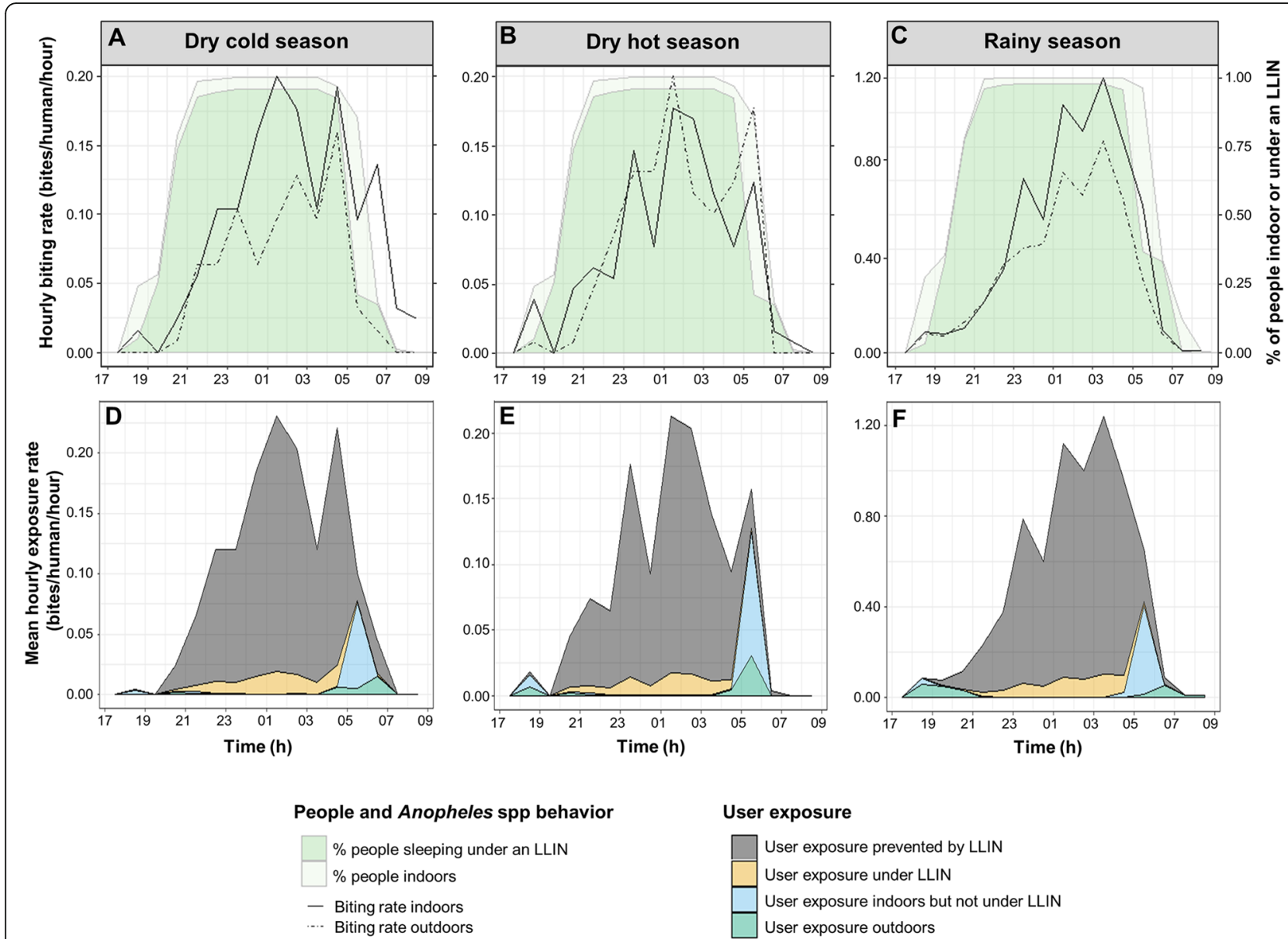

Fig. 3 Hourly human and Anopheles spp. behavior ( $\mathbf{a}, \mathbf{b}, \mathbf{c}$ ) and hourly exposure to bites of LLIN users (d, e, f), Burkina Faso. Human behavioural data in panel $A$ and $B$ are the same (only one dry season survey) but plotted with different entomological data

Diébougou. In 2017, 28 countries in the world have implemented IRS in combination with LLINs to combat malaria [2]. IRS contributed to an estimated $10(5-14) \%$ of the reduction in malaria burden achieved recently [1]. When used together, IRS and LLINs are expected to target vectors at different stages of their gonotrophic cycle using insecticides with different mode of action. However, trials assessing the impact of the combination IRS + LLIN over LLIN use alone have yielded conflicting results [46-51]. House improvement is another indoor measure which needs careful consideration and deep investigations. Indeed, house improvement has been strongly associated with reduced malaria transmission and disease in many studies [52-54]. The main house improvement interventions studied are closed eaves, closed ceilings, window screens and metal-roof houses as opposed to eaves, ceilings, windows openings and thatched-roof houses. Such improvements protect against malaria by providing physical barriers that prevent vectors from entering houses and can reduce vector survivorship [52, 55]. Nonetheless, there is compelling evidence that even a full coverage of effective measures within houses would not be sufficient to suppress transmission of malaria in Africa [56].

In this study, we evidenced that a significant proportion of LLIN users exposure to vector bites occurred outdoors (ranging from 9.48 to $30.43 \%$ ), with the highest estimate recorded in adults (over the age of 18 years old) during the dry hot season. Many studies conducted in various areas of Africa reported similar or even higher estimates of exposure occurring outdoors $[15,16,18$, 45]. Recently, a systematic review categorized Burkina Faso along with Eritrea, Ethiopia, Gabon, and Tanzania as countries with high levels of outdoor vector biting [10]. However, our results do not fully support this categorization since we show that both LLIN users and LLIN non users are far more exposed to vector bites indoors than outdoors in the study area. Nevertheless, strategies targeting outdoor bites would probably be required to achieve malaria elimination in the area.

Almost all the existing indoor vector control strategies face two important evolutive challenges. First, they 
induce a strong selective pressure on physiological resistance in vector populations because they almost all rely on synthetic chemicals [57]. Second, they also induced selective pressure for behavioral changes in vector populations resulting in a reduced contact with interventions [57]. In this context, there is a crucial need to monitor these resistance mechanisms, as well as residual transmission, after the deployment of strategies to inform decision makers in order to allow them to adapt their strategic plans.

\section{Conclusions}

This study showed that the use of LLINs prevented more than $80 \%$ of Anopheles bite exposure. Nevertheless, LLIN users are still exposed to vector bites which occurred mostly indoors in late morning. Therefore, complementary strategies targeting indoor biting vectors in combination with LLIN are expected to be the most efficient to control residual malaria transmission in this area.

\section{Supplementary Information}

The online version contains supplementary material available at https:/doi. org/10.1186/s12889-021-10304-y.

Additional file 1 Model specification. Formulae used to calculate mean exposure to bite, true average personal protection efficacy of LLINS ( $\left.P^{*}\right)$, proportions of indoor $\left(\pi_{i}\right.$ and $\left.\pi_{i, n}\right)$, "before bed" $\left(\pi_{e}\right.$ and $\left.\pi_{e, n}\right)$ and "after bed" $\left(\pi_{m}\right.$ and $\pi_{m, n}$ ) exposure to bite.

Additional file $\mathbf{2}$ LLIN Use rate per village. N: number.

Additional file $\mathbf{3}$ True average protection efficacy of LLINs against transmission and Proportions of indoors, early evening and late morning exposure to Anopheles bites per village. NA: Not Applicable.

\section{Abbreviations}

HBS: Human behaviours surveys; HLC: Human landing catch; ER: Endophagy Rate; IRS: Indoor Residual Spraying; LLIN: Long-Lasting Insecticidal Nets; ODK: Open Data Kit; NMCP: National Malaria Control Programs; WHO: World Health Organization

\section{Acknowledgements}

We acknowledge the Burkina Faso Ministry of Health, particularly Dr. Dembélé Henri and local medical team who facilitated the data collection. We thank all the villagers and local authorities for their kind collaboration throughout the study. Special thanks are due to Mr. Maiga Issouf for his strong commitment during human behavioural surveys. We are very grateful to Mr. Dahounto Amal for their substantial contributions and collaboration. We thank all the IRSS field staff for their assistance and the "Laboratoire Mixte International sur les Maladies à Vecteurs" (LAMIVECT) for their technical support. We also thank Mr. Ouattara Adama and Mr. Zoumenou Felix for their administrative support.

\section{Authors' contributions}

NM, RKD and DDS conceived and designed the study. DDS and SC collected the data. DDS and NM analyzed the data. DDS and BZ drafted the manuscript. NM, CP, PT, AS, LMB, GAO, AK and RKD reviewed the manuscript; all authors read and approved the final manuscript.

\section{Funding}

This work was part of the REACT project, funded by the French Initiative 5\% - Expertise France (No. 15SANIN213).

The funders had no role in study design, data collection and analysis, decision to publish, or preparation of the manuscript.

\section{Availability of data and materials}

The datasets used and/or analyzed during the current study are available from the corresponding author on reasonable request.

\section{Ethics approval and consent to participate}

The protocol of this study was reviewed and approved by the Institutional Ethics Committee of the Institut de Recherche en Sciences de la Santé (IECIRSS) and registered as NA06/2016/CEIRES. We received community agreement before the beginning of human and Anopheles spp. behavioral surveys. Behavioral surveys did not involve participants under 16 years old. Indeed, questionnaires were administrated only to the heads of households and information relative to children under 16 years old were therefore directly collected from either a parent or guardian. Mosquito collectors were over 16 years old. All participants (to behavioral surveys or mosquito collections) gave their written informed consent. Mosquito collectors and supervisors received a vaccine against yellow fever as a prophylactic measure. Collectors were treated free of charge for malaria according to WHO recommendations.

\section{Consent for publication}

Not applicable.

\section{Competing interests}

The authors declare that they have no competing interests.

\section{Author details}

${ }^{1}$ Institut de Recherche en Sciences de la Santé (IRSS), Bobo-Dioulasso, Burkina Faso. ${ }^{2}$ Université Nazi Boni (UNB), Bobo-Dioulasso, Burkina Faso. ${ }^{3}$ MIVEGEC, Univ. Montpellier, CNRS, IRD, Montpellier, France. ${ }^{4}$ Institut Pierre Richet (IPR), Bouaké, Côte d'Ivoire. ${ }^{5}$ Université d'Abomey Calavi, Abomey-Calavi, Benin.

Received: 21 November 2019 Accepted: 21 January 2021

Published online: 30 January 2021

References

1. Bhatt S, Weiss DJ, Cameron E, Bisanzio D, Mappin B, Dalrymple U, et al. The effect of malaria control on Plasmodium falciparum in Africa between 2000 and 2015. Nature. 2015:526:207-11.

2. WHO. World malaria report 2018; 2018. p. 1-238. Available from: http:// www.who.int/malaria/publications/world-malaria-report-2018

3. Dabiré KR, Diabaté A, Djogbenou L, Ouari A, Guessan RN, Ouédraogo J, et al. Dynamics of multiple insecticide resistance in the malaria vector. Malar J. 2008:9:1-9.

4. Toé KH, Jones CM, N'fale S, Ismai HM, Dabiré RK, Ranson H. Increased pyrethroid resistance in malaria vectors and decreased bed net effectiveness Burkina Faso. Emerg Infect Dis. 2014;20:1691-6.

5. Toé $\mathrm{KH}$, N'Falé S, Dabiré RK, Ranson H, Jones $\mathrm{CM}$. The recent escalation in strength of pyrethroid resistance in Anopheles coluzzi in West Africa is linked to increased expression of multiple gene families. BMC Genomics. 2015;16:1-11.

6. Ojuka P, Boum Y, Denoeud-Ndam L, Nabasumba C, Muller Y, Okia M, et al. Early biting and insecticide resistance in the malaria vector Anopheles might compromise the effectiveness of vector control intervention in southwestern Uganda. Malar J. 2015;14:1-8.

7. Moiroux N, Gomez MB, Pennetier C, Elanga E, Djènontin A, Chandre F, et al. Changes in Anopheles funestus biting behavior following universal coverage of long-lasting insecticidal nets in Benin. J Infect Dis. 2012;206:1622-9.

8. Fornadel CM, Norris LC, Glass GE, Norris DE. Analysis of Anopheles arabiensis blood feeding behavior in southern zambia during the two years after introduction of insecticide-treated bed nets. Am J Trop Med Hyg. 2010;83: 848-53

9. Ranson H, Lissenden N. Insecticide resistance in African Anopheles mosquitoes: a worsening situation that needs urgent action to maintain malaria control. Trends Parasitol. 2016:32:187-96 Available from: https://doi. org/10.1016/j.pt.2015.11.010.

10. Sherrard-Smith E, Skarp JE, Beale AD, Fornadel C, Norris LC, Moore SJ, et al. Mosquito feeding behavior and how it influences residual malaria transmission across Africa. Proc Natl Acad Sci U S A. National Academy of Sciences. 2019;116:15086-95.

11. WHO. Global strategy for dengue prevention and control 2012-2020. 2012. 
12. Killeen GF, Tatarsky A, Diabate A, Chaccour CJ, Marshall JM, Okumu FO, et al. Developing an expanded vector control toolbox for malaria elimination. BMJ Glob Heal. 2017;2:1-9.

13. Barreaux P, Barreaux AMG, Sternberg ED, Suh E, Waite JL, Whitehead SA, et al. Priorities for broadening the malaria vector vontrol tool kit. Trends Parasitol. 2017;33:763-74.

14. Kelly-Hope LA, FE MK. The multiplicity of malaria transmission: A review of entomological inoculation rate measurements and methods across subSaharan Africa. Malar. J; 2009. p. 19

15. Killeen GF, Kihonda J, Lyimo E, Oketch FR, Kotas ME, Mathenge E, et al. Quantifying behavioural interactions between humans and mosquitoes evaluating the protective efficacy of insecticidal nets against malaria transmission in rural Tanzania. BMC Infect Dis. 2006;6:1-10.

16. Geissbühler Y, Chaki P, Emidi B, Govella NJ, Shirima R, Mayagaya V, et al. Interdependence of domestic malaria prevention measures and mosquitohuman interactions in urban Dar Es Salaam. Tanzania Malar J. 2007;6:1-17.

17. Seyoum A, Sikaala $\mathrm{CH}$, Chanda J, Chinula D, Ntamatungiro AJ, Hawela M, et al. Human exposure to anopheline mosquitoes occurs primarily indoors, even for users of insecticide- treated nets in Luangwa Valley, South-East Zambia. Parasit Vectors. 2012;5:1-10

18. Huho B, Briët O, Seyoum A, Sikaala C, Bayoh N, Gimnig J, et al. Consistently high estimates for the proportion of human exposure to malaria vector populations occurring indoors in rural Africa. Int J Epidemiol. 2013;42:23547

19. Bayoh MN, Walker ED, Kosgei J, Ombok M, Olang GB, Githeko AK, Killeen GF, Otieno P, Desai M, Lobo NF, Vulule JM, Hamel MJ, SK and JEG. Persistently high estimates of late night, indoor exposure to malaria vectors despite high coverage of insecticide treated nets. Parasit Vectors. 2014;7:1-13.

20. Moiroux N, Damien GB, Egrot M, Djenontin A, Chandre F, Corbel V, et al. Human exposure to early morning Anopheles funestus biting behavior and personal protection provided by long-lasting insecticidal nets. PLoS One. 2014;9:8-11.

21. Cooke MK, Kahindi SC, Oriango RM, Owaga C, Ayoma E, Mabuka D, et al. "A bite before bed": exposure to malaria vectors outside the times of net use in the highlands of western Kenya. Malar J. 2015;14:1-15.

22. Bradley J, Lines J, Fuseini G, Schwabe C, Monti F, Slotman M, et al. Outdoor biting by Anopheles mosquitoes on Bioko Island does not currently impact on malaria control. Malar J. 2015;14:1-8.

23. Kamau A, Mwangangi JM, Rono MK, Mogeni P, Omedo I, Midega J, et al. Variation in the effectiveness of insecticide treated nets against malaria and outdoor biting by vectors in Kilifi, Kenya. Wellcome Open Res. 2017;2:1-56.

24. Finda MF, Moshi IR, Monroe A, Limwagu AJ, Nyoni AP, Swai JK, et al. Linking human behaviours and malaria vector biting risk in South-Eastern Tanzania. PLoS One. 2019;14:e0217414.

25. Pollard EJM, MacLaren D, Russell TL, Burkot TR. Protecting the peri-domestic environment: the challenge for eliminating residual malaria. Sci Rep. 2020; 10:1-9.

26. Monroe A, Moore S, Koenker H, Lynch M, Ricotta E. Measuring and characterizing night time human behaviour as it relates to residual malaria transmission in sub - Saharan Africa : a review of the published literature. Malar J. 2019;18:1-12. Available from. https://doi.org/10.1186/s12936-019-2638-9.

27. Monroe A, Msaky D, Kiware S, Tarimo BB, Moore S, Haji K, et al. Patterns of human exposure to malaria vectors in Zanzibar and implications for malaria elimination efforts. Malar J. 2020;19:1-14. Available from. https://doi.org/10. 1186/s12936-020-03266-W.

28. Thomsen EK et al. Mosquito behaviour change after distribution of bednets results in decreased protection against malaria exposure. J Infect Dis. 2017; $X X: 1-8$.

29. Govella NJ, Maliti DF, Mlwale AT, Masallu JP, Mirzai N, Johnson PCD, et al. An improved mosquito electrocuting trap that safely reproduces epidemiologically relevant metrics of mosquito human-feeding behaviours as determined by human landing catch. Malar J. 2016;15:1-17.

30. Sougoufara S, Thiaw O, Cailleau A, Diagne N, Harry M, Bouganali C, et al. The impact of periodic distribution campaigns of long-lasting insecticidaltreated bed nets on malaria vector dynamics and human exposure in Dielmo, Senegal. Am J Trop Med Hyg. 2018;98:1343-52.

31. Soma DD, Zogo BM, Somé A, Tchiekoi BN, de Sales Hien DF, Pooda HS, et al. Anopheles bionomics, insecticide resistance and malaria transmission in Southwest Burkina Faso: a pre-intervention study. PLoS One. 2020:15:1-21.
32. INSD. Tableau de bord économique et social 2014 de la région du Sud Ouest. 2015

33. INSD. Enquête nationale sur le secteur de l'orpaillage (ENSO). 2017.

34. Mattingly P, F P, Rageau J. Contributions de la faune des moustiques du Sud-Est Asiatique: 12. Clés illustrées des genres de moustiques. Contrib Am Entomol Inst. 1971:7:1-86.

35. Gillies M, Coetzee M. A supplement to the Anophelinae of Africa South of the Sahara (Afrotropical Region). South African Inst Med Res. 1987:143:1-143.

36. Koekemoer LL, Kamau L, Hunt RH, Coetzee M. A cocktail polymerase chain reaction assay to identify members of the Anopheles funestus (Diptera: Culicidae) group. Am J Trop Med Hyg. 2002;66:804-11.

37. Cohuet A, Simard F, Berthomieu A, Raymond M, Fontenille DWM. Isolation and characterization of microsatellite DNA markers in the malaria vector Anopheles funestus. Mol Ecol Notes. 2002;2:498-500.

38. Santolamazza F, Mancini E, Simard F, Qi Y, Tu Z. Della Torre a. insertion polymorphisms of SINE200 retrotransposons within speciation islands of Anopheles gambiae molecular forms. Malar J. 2008;7:1-10 Available from: http://www.malariajournal.com/content/7/1/163

39. The R Development Core Team. R : A Language and Environment for Statistical Computing; 2008. p. 1-2547. Available from: http://www.gnu.org/ copyleft/gpl.html

40. Olapeju B, Choiriyyah I, Lynch M, Acosta A, Blaufuss S, Filemyr E, et al. Age and gender trends in insecticide-treated net use in sub-Saharan Africa: a multi-country analysis. Malar J. 2018;17:423.

41. WHO. World malaria report 2017. World heal. Organ. 2017. Available from: http://www.who.int/malaria/publications/world-malaria-report-2017

42. Krezanoski PJ, Bangsberg DR, Tsai AC. Quantifying bias in measuring insecticide-treated bednet use: meta-analysis of self-reported vs objectively measured adherence. J Glob Health. Edinburgh University Global Health Society. 2018;8:1-11.

43. Koudou BG, Malone D, Hemingway J. The use of motion detectors to estimate net usage by householders, in relation to mosquito density in central Cote d'Ivoire: Preliminary results. Parasites and Vectors. 2014;7:1-6.

44. Krezanoski PJ, Santorino D, Agaba A, Dorsey G, Bangsberg DR, Carroll RW. How are insecticide-treated bednets used in ugandan households? A comprehensive characterization of bednet adherence using a remote monitor. Am J Trop Med Hyg. 2019;101:404-11.

45. Russell TL, Govella NJ, Azizi S, Drakeley CJ, Kachur SP, Killeen GF. Increased proportions of outdoor feeding among residual malaria vector populations following increased use of insecticide-treated nets in rural Tanzania. Malar J. 2011;10:1-10 Available from: http://www.malariajournal.com/content/10/1/ 80.

46. West PA, Protopopoff N, Wright A, Kivaju Z, Tigererwa R, Mosha FW, et al. Indoor residual spraying in combination with insecticide-treated nets compared to insecticide- treated nets alone for protection against malaria : a cluster randomised trial in Tanzania. PLoS Med. 2014;11:1-12.

47. Protopopoff N, Mosha JF, Lukole E, Charlwood JD, Wright A, Mwalimu CD, et al. Effectiveness of a long-lasting piperonyl butoxide-treated insecticidal net and indoor residual spray interventions, separately and together, against malaria transmitted by pyrethroid-resistant mosquitoes: a cluster, randomised controlled, two-by-two fact. Lancet. 2018;391:1577-88. Available from:. https://doi.org/10.1016/S0140-6736(18)30427-6.

48. Kafy HT, Ismail BA, Mnzava AP, Lines J, Abdin MSE, Eltaher JS, et al. Impact of insecticide resistance in Anopheles arabiensis on malaria incidence and prevalence in Sudan and the costs of mitigation. Proc Natl Acad Sci. 2017; 114:E11267-75

49. Corbel V, Akogbeto M, Damien GB, Djenontin A, Chandre F, Rogier C, et al. Combination of malaria vector control interventions in pyrethroid resistance area in Benin: a cluster randomised controlled trial. Lancet Infect Dis. 2012;12:617-26.

50. Pinder M, Jawara M, Jarju LBS, Salami K, Jeffries D, Adiamoh M, et al. Efficacy of indoor residual spraying with dichlorodiphenyltrichloroethane against malaria in Gambian communities with high usage of long-lasting insecticidal mosquito nets: a cluster-randomised controlled trial. Lancet. 2015:385:1436-46

51. Loha E, Deressa W, Gari T, Balkew M, Kenea O, Solomon T, et al. Longlasting insecticidal nets and indoor residual spraying may not be sufficient to eliminate malaria in a low malaria incidence area: results from a cluster randomized controlled trial in Ethiopia. Malar J. 2019:18:1-15.

52. Tusting LS, Ippolito MM, Willey BA, Kleinschmidt I, Dorsey G, Gosling RD, et al. The evidence for improving housing to reduce malaria: A systematic review and meta-analysis. Malar. J. 2015;14:1-12. 
53. Rek JC, Alegana V, Arinaitwe E, Cameron E, Kamya MR, Katureebe A, et al. Rapid improvements to rural Ugandan housing and their association with malaria from intense to reduced transmission: a cohort study. Lancet Planet Heal. 2018:2:83-94

54. Killeen GF, Govella NJ, Mlacha YP, Chaki PP. Suppression of malaria vector densities and human infection prevalence associated with scale-up of mosquito-proofed housing in Dar Es Salaam, Tanzania: re-analysis of an observational series of parasitological and entomological surveys. Lancet Planet Heal. 2019;3:e132-43.

55. Lindsay SW, Jawara M, Mwesigwa J, Achan J, Bayoh N, Bradley J, et al. Reduced mosquito survival in metal-roof houses may contribute to a decline in malaria transmission in sub-Saharan Africa. Sci Rep. Nat Publ Group. 2019;9:7770.

56. WHO. Control of residual malaria parasite transmission. WHO Media Cent. 2014:11:1-5 Available from: http://www.who.int/malaria/publications/atoz/ technical-note-control-of-residual-malaria-parasite-transmission-sep 14.pdf.

57. Lies $D$, Marc $C$. Residual transmission of malaria: an old issue for new approaches. Anopheles mosquitoes - New insights into malaria vectors. Intech Open Science. 2013; 21: 671-704. Available from: http://www. intechopen.com/books/anopheles-mosquitoes-new-insights-into-malariavectors

\section{Publisher's Note}

Springer Nature remains neutral with regard to jurisdictional claims in published maps and institutional affiliations.

Ready to submit your research? Choose BMC and benefit from:

- fast, convenient online submission

- thorough peer review by experienced researchers in your field

- rapid publication on acceptance

- support for research data, including large and complex data types

- gold Open Access which fosters wider collaboration and increased citations

- maximum visibility for your research: over $100 \mathrm{M}$ website views per year

At BMC, research is always in progress.

Learn more biomedcentral.com/submissions 